\title{
2. Advances in Genomics and Genetics of Penaeid Shrimp
}

\author{
Javier Robalino ${ }^{1}$, Robert W. Chapman ${ }^{2}$, Enrique de la Vega ${ }^{3}$, Nuala A. O'Leary ${ }^{4}$, Danielle M. \\ Gorbach $^{5}$, Zhi-Qiang Du ${ }^{5}$, Max F. Rothschild ${ }^{5}$, Craig L. Browdy ${ }^{6}$, Gregory W. Warr ${ }^{4}$, Yannick \\ Labreuche $^{4}$
}

\footnotetext{
${ }^{1}$ Facultad de Ingeniería Marítima y Ciencias del Mar, Escuela Superior Politécnica del Litoral, Prosperina, Guayaquil, Ecuador

${ }^{2}$ Marine Resources Research Institute, South Carolina Department of Natural Resources, Charleston, SC, USA

${ }^{3} \mathrm{CI}$ OCEANOS, Cartagena, Colombia

${ }^{4}$ Marine Biomedicine and Environmental Sciences Center, Medical University of South Carolina, Charleston, SC, USA

${ }^{5}$ Department of Animal Science and Center for Integrated Animal Genomics, Iowa State University, Ames, IA, USA

${ }^{6}$ Novus International Inc., Charleston, SC, USA
}

\section{Abstract:}

This chapter contains sections titled:

Introduction

EST Collection as an Approach to Gene Discovery in Shrimp

Medium- to High-Throughput Studies of Differential Expression and Gene Discovery

RNAi-Based Applications in Shrimp Aquaculture: From Reverse Genetics to Control of Diseases

Markers, Genetic Maps, and Large Insert Genomic Libraries in Shrimp

Analytical Challenges in Genomics and Genetics of Shrimp

Concluding Remarks

Acknowledgments

References

Keywords: penaeid shrimp; EST collection, gene discovery; gene expression "snapshot"; gametogenesis; abiotic stress responses; differential expression cloning; RNAi-based applications, shrimp; targeted gene silencing; RNAi, and gene function; genetic markers in breeding 
Penaeid shrimp constitute one of the most important groups of species for aquaculture worldwide, ranking second overall in value in 2006 (FAO 2007). Sustainable development of this industry could greatly benefit from progress in our basic knowledge of genetics, genomics, and molecular immunology of shrimp. Recently, the application of high throughput molecular tools and approaches has led to significant developments in these fields. This chapter describes the current status of efforts to catalogue the transcriptome of shrimp through the collection, curation, data base development, and analyses of expressed sequence tags (ESTs) and through analysis of differential gene expression. Advances in the development of other genetic resources such as genetic maps and genomic libraries are also discussed. We emphasize how these tools can and are providing new molecular information about biological processes of relevance to shrimp aquaculture, such as immune responses and reproductive physiology. We then consider the contributions of reverse genetics through RNA-mediated interference (RNAi), which is now being used to test the involvement of specific genes in aquaculture-relevant traits. Proof-of-concept studies also demonstrate that RNAi is a promising approach to the development of antiviral therapies. Future developments in shrimp genetics and genomics that will further contribute to advancing biotechnological applications in aquaculture are also discussed throughout this chapter.

\section{EST collection as an approach to gene discovery in shrimp}

ESTs are short DNA sequences generated by large scale single-pass sequencing of randomly picked cDNA clones from libraries. They generally represent a single tissue or condition of interest at a given time thus providing a "snapshot" of the physiological status of a cell, tissue or an organism. EST sequencing projects can provide an efficient and rapid means for discovering new genes, alleles and polymorphisms, thereby providing data on gene expression and regulation, and for the development of genome maps.

Genomic research by EST analysis has been conducted for several shrimp species including Penaeus monodon, Fenneropenaeus chinensis, Marsupenaeus japonicus, Litopenaeus setiferus, and Litopenaeus vannamei (Table 1). Most of these analyses have been small scale sequencing efforts conducted by individual laboratories studying mostly shrimp immunity and disease, and have contributed to the identification of a significant number of previously undescribed genes.

In contrast to small scale EST projects, when large sequencing efforts are conducted the rate of return of novel genes rapidly decreases as sequencing progresses. This is caused by a small number of genes producing large quantities of mRNA and appearing as highly redundant in the EST clones being sequenced. Therefore, for this kind of initiative it is recommended to use some form of normalization or redundancy subtraction to maximize the rate of gene discovery (Soares et al. 1994). We have used a direct redundancy subtraction method which involves subtracting highly redundant genes from arrayed cDNA libraries (E. de la Vega and N. O'Leary, unpublished). Briefly, the process involves producing a typical cDNA library, which is then plated onto large agar plates with antibiotic selection and single colonies are picked robotically into 384 well plates. The resulting 
library is robotically spotted at high density onto nitrocellulose membranes and direct redundancy subtraction is achieved by sequencing 384 samples and identifying the most redundant clones. These clones are then used to produce probes which are hybridized to the membranes, highly redundant genes are thereby identified, and those clones which did not hybridize to the probes are then "cherry picked" and re-arrayed. This whole process yields a low redundancy library which increases the rate of gene discovery (Figure 1). This approach has been used to sequence more than 150,000 ESTs from hemocytes, gills, hepatopancreas, lymphoid organ, ventral nerve cord and eyestalk of $L$. vannamei, resulting in the identification of around 15,000 unigenes. All these ESTs are publicly available at the NCBI EST database (http://www.ncbi.nlm.nih.gov/dbEST) or at the Marine Genomics website (www.marinegenomics.org). This and other efforts have contributed, as of January 2009, a total of 179,032 ESTs for Penaeid shrimp (http://www.ncbi.nlm.nih.gov/dbEST/dbEST_summary.html).

Although the comprehensive annotation of the now abundant EST data available for $L$. vannamei is at a very early stage, it is expected to yield a large number of novel genes involved in immunity, respiration, endocrinology, and digestion, among others, providing an opportunity to better understand the physiology of shrimp. In addition, large numbers of molecular markers such as single nucleotide polymorphisms (SNPs) or microsatellite markers are expected to be mined out of these sequences, making them available for shrimp breeding programs interested in using marker assisted selection. Some efforts in this respect have already been reported (see discussion later in this chapter) and show promise in the ability to use this EST information for marker development.

\section{Medium to high throughput studies of differential expression and gene discovery}

While ESTs can provide a "snapshot" of gene expression in a tissue of interest, it is not a cost-effective approach to identifying differential gene expression in multiple samples. Differential expression is often of particular interest as a first approach to understanding gene function. The presumption that expression of a gene is largely restricted to the cell or tissue where it is needed, at the time when it is needed, provides the rationale for the significant attention given to this issue. In shrimp of aquaculture significance, medium to high throughput methods for assessing changes in gene expression have been most intensively applied to studying the response to pathogens and to stimulators of the immune system.

For species where the expected gene content vastly exceeds the number of known genes (which is the case in shrimp), methods of assessing changes in gene expression that do not rely on previously known sequence information are particularly useful. Two widely used methods of this kind, Suppression Subtractive Hybridization (SSH, (Diatchenko et al. 1996)) and mRNA Differential Display (DD, (Liang and Pardee 1992)), are aimed at the isolation of cDNA fragments derived from differentially expressed genes. Comparative analyses of Expressed Sequence Tags (ESTs), isolated from tissues or cells subjected to conditions of interest, can also be used as a means of identifying genes potentially regulated by such conditions (see Table 1 for examples). All these methods are exploratory in nature, each subject to caveats and biases of their own, such that 
independent experimental confirmation of differential expression by direct methods (such as quantitative reverse-transcription PCR) is essential. SSH and DD are especially limited in terms of direct discovery of new genes in understudied species, because they involve the isolation of short cDNA fragments, rather than full-length cDNAs. SSH and DD are also less amenable than traditional EST mining to high throughput sequencing, as the complexity of the cDNA pools obtained by these methods is generally low.

Processes of interest to shrimp aquaculture that have been studied using differential expression cloning approaches include gametogenesis, abiotic stress responses, and immune responses (Table 2). Many of the sequences isolated from these studies do not allow identification of genes with predictable homology or function. Presumably, some of these sequences correspond to novel genes, while others represent poorly conserved and/or short regions from otherwise conserved genes.

A markedly different approach to study differential gene expression at high throughput is the use of microarray technology. Microarrays are arrangements of DNAs immobilized to solid supports in such a way that each element in the arrangement corresponds to a single known DNA sequence. Probing these arrangements with mRNA (or the corresponding cDNA) obtained from animals of interest allows a quantitative assessment of the expression of each gene whose sequence is represented on the microarray. Remarkably, thousands to millions of such DNA elements can be simultaneously evaluated due to the capacity of current technology to immobilize DNA on surfaces at extremely high densities. Microarrays with gene contents ranging from a few dozen to a few thousand genes have been generated and used to study expression in L. vannamei, P. monodon, L. stylirostris, $M$. japonicus, and $F$. chinensis. In Table 3 some of these studies are summarized, in terms of the nature of the microarrays developed, and in terms of their most significant findings potentially relevant to aquaculture.

New gene discovery and the identification of differentially expressed genes provide only an initial step towards better understanding shrimp biology, and towards using such information to improve shrimp aquaculture. For almost every shrimp gene considered in the studies described in tables 1,2 and 3, the most critical experimental information necessary to understand its function is still lacking. However, for some of the genes found to be regulated during immune challenge, functional follow-up studies have started to define their roles in the defense from pathogens (see next section on shrimp RNAi studies). These types of investigations can begin to elucidate immune pathways, improving our fundamental understanding of shrimp immunity. Furthermore, such genes represent good candidates for markers of disease resistance in breeding efforts, and for the development of tools useful to monitor shrimp health in aquaculture settings. Thus, the discovery of genes that are differentially expressed in situations of interest, coupled with subsequent functional characterization of the gene products, provide important avenues to the development of biotechnological tools for aquaculture.

\section{RNAi-based applications in shrimp aquaculture: from reverse genetics to} control of diseases

First described in nematodes (Fire et al. 1998) and subsequently in most eukaryotes studied so far, RNA interference (RNAi) is a highly conserved nucleic acid-based 
mechanism, mediating sequence-specific targeted gene silencing. This machinery is initiated by double-stranded RNA (dsRNA), which is processed by a Dicer family member into small effector RNA duplexes (e.g. siRNAs, miRNAs, esiRNAs, etc). The small RNAs are incorporated onto a multimeric protein complex, the RNA-induced silencing complex (RISC) and related complexes, which mediate targeted degradation, translational repression, and other silencing phenomena by means of complementary base-pairing. Because dsRNA or short interfering RNAs (siRNAs) can be supplied exogenously to trigger specific gene silencing, RNAi has rapidly become the most widely used gene silencing tool in a broad variety of eukaryotic organisms [reviewed in (Campbell and Choy 2005)]. In this section, we review current RNAi-based research in shrimp and discuss future applications of this phenomenon in shrimp aquaculture.

\section{RNAi mechanisms in shrimp}

The existence of an intact RNAi machinery in shrimp was first proposed by Robalino and collaborators, who demonstrated in L. vannamei that in vivo administration of dsRNA induced a down-regulation of endogenous or viral gene expression in a sequence-specific manner (Robalino et al. 2005). Additional evidence came from the identification of possible RNAi pathway components in the black tiger shrimp $P$. monodon: Pem-AGO (Dechklar et al. 2008); Pm-Ago, another member of the Argonaute protein family (Unajak et al. 2006), and a Dicer nuclease, Pm-Dcr1 (Su et al. 2008). However, more work will be necessary to define the roles (if any) played by each of these components in shrimp RNAi. Nevertheless, these results strongly suggest the existence of functional RNAi in shrimp and have opened the possibility, for the first time, of using reverse genetic approaches to understand gene function in these organisms.

\section{Methods to trigger gene silencing by RNAi in shrimp}

In shrimp, targeted gene silencing has been experimentally induced by several methods: in vivo injection, in vitro delivery to primary cell cultures, and feeding bacteria carrying dsRNA in vivo.

Injection of dsRNA: Several studies have shown in different shrimp species the ability of ectopic dsRNA to spread from the site of injection (pereiopod, tail muscle) to distant tissues to mediate a potent depletion of cognate mRNAs, thus facilitating reliable and reproducible gene silencing experiments (Table 4). However, several factors that are likely to affect silencing efficiency, such as target sequence selection and dsRNA dose, are still in need of detailed study in the different shrimp species. Altogether, injection of long dsRNA is to date the most widely used method for interrupting gene expression in shrimp in vivo.

Injections of siRNAs to induce knockdown of target gene expression have also been reported in shrimp (Table 4). Generated by cleavage of dsRNA by Dicer, siRNAs are 21 25-mer duplexes that confer sequence specificity to the silencing complexes. In mammals, siRNAs are extensively used because of their great specificity and efficacy, but also because these duplexes are small enough to bypass the induction of potent immune responses elicited by longer dsRNAs (Elbashir et al. 2001). In shrimp, important discrepancies in obtained results have been observed when using siRNAs in vivo (see 
Table 4). Results ranging from no silencing at all to highly effective silencing have been reported. The existence of different mechanisms for uptake of siRNA, selection and design methods of target sequences for RNAi or duration of siRNA activity in vivo have been hypothesized to explain these inconsistencies (Shekhar and Lu 2009). These issues warrant further investigation.

in vitro delivery to primary cell cultures: Few studies have demonstrated in shrimp the application of RNAi in transfection experiments (Tirasophon et al. 2005; Assavalapsakul et al. 2006; Dechklar et al. 2008). Because of the unavailability of clonal long-term cell lines in marine invertebrates (Rinkevich 2005), gene-specific dsRNA transfection experiments have been performed into primary cultures of lymphoid (Oka) cells, leading to downregulation of endogenous or viral cognate mRNAs. Recently, Treerattrakool et al. described successful RNAi-mediated knockdown by dsRNA adjunction to P. monodon eyestalk ganglia and abdominal nerve cord explant cultures (Treerattrakool et al. 2008). These studies expand significantly the experimental capabilities for exploring gene function in shrimp, allowing the study of organ-specific phenomena outside of the context of the whole animal.

Feeding or bacteria-mediated RNAi: Establishing RNAi by bacterial feeding was first envisioned in Caenorhabditis elegans (Timmons and Fire 1998) and later in planarians (Newmark et al. 2003), plants (Tenllado et al. 2003), and insects (Walshe et al. 2008). In shrimp, progress has been made recently in the use of non-pathogenic bacteria to induce gene silencing. Sarathi and colleagues were the first to report the production of dsRNA using prokaryotic expression systems for RNAi purposes in P. monodon (Sarathi et al. 2008a). Later, these authors investigated in vivo whether bacterially expressed dsRNA derived from viral sequences could specifically interfere with viral infection following oral administration. Two different delivery approaches were tested: animals were fed with pellet feed coated either with inactivated bacteria containing overexpressed dsRNA, or with bacterially expressed dsRNA entrapped onto chitosan nanoparticles. Both feeding methodologies were conclusive, the best results being obtained when feed was coated with inactivated bacteria expressing dsRNA (Sarathi et al. 2008b).

\section{RNAi as a tool to unravel gene function in vivo}

As previously discussed, EST mining and differential expression cloning have been applied in shrimp to gain insight into gene function. Ultimately however, experimental manipulation of expression is necessary to directly address issues of function. In shrimp, RNAi is to date the only reliable tool for this type of experimentation. An increasing number of studies have resolved, in the recent past, gene functions involved in moulting, osmoregulation, reproduction, or glucose metabolism in shrimp by using gene-specific dsRNA/siRNA technology (Table 4). Although gene silencing by dsRNA can complicate immunology studies in shrimp due to non-specific stimulation of antiviral responses (Robalino et al. 2004), it is possible to perform carefully designed experiments to explore at least some aspects of their immune system (de la Vega et al. 2008; Shockey et al. 2008; Amparyup et al. 2009). These studies are of great relevance to biotechnology in aquaculture, as they pave the way to start defining the relationship between known genes and traits of commercial importance. 
The spread of infections due to geographically widespread viruses has led to huge economic losses in the shrimp farming industry, threatening its economic viability and long-term sustainability in some regions of the world (Lightner and Redman 1998; Lightner et al. 2006). To control the occurrence and spread of viral diseases, new strategies for disease prevention, such as exposure to inactivated virus or viral proteins, are currently being developed [reviewed in (Johnson et al. 2008)]. Because the RNAi machinery allows gene silencing in a highly sequence-specific manner with little or no risk of undesired offtarget effects, injections of viral gene-specific dsRNA/siRNA into shrimp seem to be a more powerful and attractive tool to inhibit viral replication and/or protect shrimp from viral infections than other methods. Indeed, this strategy has proven to be effective against three unrelated viruses (Table 1) [see (Shekhar and Lu 2009) for a review]. Furthermore, as previously discussed, feeding of dsRNA has already been proven as a feasible approach to block viral pathogenesis in vivo (Sarathi et al. 2008b), opening the door to the development of dsRNA-based treatments applicable at a commercial scale.

\section{Markers, genetic maps, and large insert genomic libraries in shrimp}

The development of genetic markers for breeding purposes has been an area of significant interest among shrimp researchers for several years. Several types of markers, including microsatellites, Restriction Fragment Length Polymorphisms (RFLPs), Amplified Fragment Length Polymorphisms (AFLPs), and Randomly Amplified Polymorphic DNAs (RAPDs) have been developed, to different extents, in several Penaeid species [for examples see (Garcia et al. 1994; Xu et al. 1999; Wilson et al. 2002; Meehan et al. 2003)]. Here, we will focus mostly on how the new genomic resources previously described in this chapter have provided new opportunities for the identification of Single Nucleotide Polymorphisms (SNPs). Some significant efforts in the generation of genetic maps with large numbers of markers of diverse types will also be mentioned. Finally, we will briefly comment on the status of large DNA libraries for shrimp, a resource that will prove essential for the future of genomics in these species.

\section{Single Nucleotide Polymorphisms (SNPs)}

Panels of genetic markers have been developed for both $L$. vannamei and $P$. monodon, consisting primarily of microsatellites and AFLPS, although a limited number of SNPs have also been reported (Glenn et al. 2005). Little genomic data is currently available for shrimp species and most of the sequence data has originated from EST libraries, which commonly may contain many sequencing errors. Consequently, locating new polymorphisms is a slow and arduous task which is best completed through the use of computer predictions or large-scale sequencing techniques. Due to the limited alternatives, the primary method for in silico prediction of SNPS has been comparison of ESTs displaying sequence similarity, despite the challenges of distinguishing sequencing errors from true base differences. One pipeline used for such predictions is to cluster the available ESTs with CAP3 (Huang and Madan 1999) and predict SNPs using SNPidentifier (Gorbach et al. 2009), which has built-in quality control measures to compensate for the inherent errors in EST sequences. Thus far, this method has produced the most validated SNPs in shrimp (768 in L. vannamei) of any published process. When the same method 
was tried using ESTs from nine other shrimp species and validated in vivo only in $L$. vannamei, the success rate of SNP prediction was decreased significantly (from $44 \%$ to 11\%)(Gorbach et al. submitted)

A smaller-scale SNP identification method that has also been utilized is sequencing candidate genes. For a gene that is suspected to play a role in an important phenotype, primers are designed to sequence a region of the gene. When successful, one or more SNPs can be identified within the sequenced region. This process has identified at least 12 SNPs in L. vannamei and at least 3 SNPs in P. monodon (Glenn et al. 2005; Yu et al. 2006; Zeng et al. 2008). One of the SNPs discovered using this process has been placed on the $P$. monodon linkage map (Maneeruttanarungroj et al. 2006). Furthermore, sequences from various other resources can also be used to identify SNPs, e.g. short tandem repeats and AFLPs.

With the development of next generation sequencing platforms, such as the Roche Genome Sequencer FLX ${ }^{\mathrm{TM}}$ system, Illumina Genome Analyzer ${ }^{\mathrm{TM}}$ and Applied Biosystems SOLiD $^{\mathrm{TM}}$ sequencing system, large-scale SNP discovery has become extremely fast and efficient, for a lower cost. Currently, none of these technologies have been applied to shrimp, but this is certainly the future for genomics in general and therefore where shrimp genomics should go in the ensuing years.

\section{Genetic maps}

Linkage maps based on microsatellite and AFLP markers have been published for both $L$. vannamei (Zhang et al. 2007) and P. monodon (Maneeruttanarungroj et al. 2006). A more complete linkage map for $P$. monodon has been constructed from AFLP markers (Staelens et al. 2008). This map identified some 44 male and 43 female linkage groups and, given the number of shrimp chromosomes (44, (Chow et al. 1990)), is likely to include the majority of chromosomal linkage groups in this species. A new linkage map for $L$. vannamei is currently under construction (Z.-Q. Du, D.M. Gorbach, and M.F. Rothschild, unpublished), which incorporates a large number of SNP markers, and may be further extended with the output from next generation sequencing technology.

\section{Large insert size genomic libraries}

Since the development of cloning methods for large DNA segments (O'Connor et al. 1989) Bacterial Artificial Chromosomes (BACs) have become the preferred means for construction of libraries containing most if not all of the genome. Usually BACs contain inserts of size $150-350 \mathrm{kbp}$, but can be as large as $750 \mathrm{kbp}$. There are several reasons for constructing such large insert libraries, which include reduced overlap of individual clones, reduction in the number of clones that must be maintained for complete genome coverage, efficiencies in DNA sequencing and genome mapping, and source material for the creation of transgenic organisms. Unfortunately, generating a stable large insert BAC library for shrimp has proven to be difficult. Several mid-sized (50 kbp) fosmid libraries have, however, been generated and at least one of these is publicly available (http://WWw.genome.clemson. edu/). While these tools are available, they have not been exploited and, thus, great opportunities are available to the community in this area. 
A well described characteristic of genomics studies is the generation of massively paralleled data sets, which will pose unprecedented analytical challenges. The well known problems are how to manage large quantities of data and mine these data for significant biologically meaningful signals (Warr et al. 2007). These are issues for all genomics studies regardless of species or the research area of interest, and the topic is frequently reviewed in the literature. Rather than rehash the issue, we chose to discuss a different topic that may be able to address some problems specific to shrimp aquaculture and potentially revise the way selective breeding in cultured species is prosecuted.

It is well known that phenotypic selection for quantitative traits in shrimp is hampered by the low observed heritabilities of certain desired traits (Perez-Rostro and Ibarra 2003) as opposed to typical values in agriculture species. This observation is consistent with what one might expect in a species, e.g. shrimp, which do not have a long history of domestication and inbreeding. For a trait like growth, which is likely influenced by a large number of genes and the environment, the absence of a long history of domestication reduces the probability that many loci will have gone to fixation by chance alone. This in turn makes it more difficult to detect the influence of individual genes that remain polymorphic in the population.

The high dimensionality of massive genomics data imposes a heavy burden on the analytical methods. How does one identify the important genetic markers when thousands to millions of genetic markers are available and only a small number of them are necessary for maximal information content? This is identical to the dimensionality reduction problem encountered in microarray analysis. Traditional linear algebra approaches (e.g. ANOVA) can only be useful for a limited number of markers, and cannot predict the phenotype when there are non-linear effects among alleles at a single locus or multigene interactions, which is almost certainly the case for most quantitative traits (cf. (Brockmann et al. 2000; Liu et al. 2007; Han et al. 2008; Ankra-Badu et al. 2009) for examples).

Different statistical and computational methods have been proposed to address the issue of dimension reduction, for instance, Bayesian Information Criteria and penalized likelihood (cf. (Manichaikul et al. 2008)), with the general conclusion that the penalized LOD score approach provides an accurate selection of QTLs and their interactions, at least in low dimensional space. Though promising, the approach taken by Manichaikul et al. (2008) is a rather brute force method which does not explore the global state space and could be more easily accomplished with Artificial Intelligence (AI) tools such as Genetic Algorithms and Genetic Programming optimization of Neural Networks (GPNN)(Ritchie et al. 2003; Motsinger et al. 2006). Artificial Neural Networks (ANNs) and Support Vector Machines (SVMs) have also been used for microarray and genotyping data (We note that SVMs using sigmoidal kernels are equivalent to a single layer ANN). The general conclusion from studies employing the Al tools is that ANNs can detect the influence of multiple genetic and environmental factors on phenotypic traits but can be computationally expensive as a dimensionality reduction tool. In our own work, SVMs using polynomial kernels have been more efficient in dimensionality reduction than ANNs, but ANNs generally provide superior classifications and models of system dynamics (R.W. Chapman, unpublished). Furthermore, advances in analytical methods in other species which are already using genomic selection are likely to be applicable for improving breeding systems in aquaculture species. 
The last decade of research and development in shrimp genomics and genetics has seen significant advancements. An abundance of sequence information from expressed genes is available in public databases, providing a first glimpse at the gene content of several Penaeid species. Researchers and aquaculture geneticists are only now beginning to exploit these resources, especially for the identification of genetic markers, candidate disease resistance genes, and genes linked to reproduction and other aquaculture-relevant processes. A growing number of initiatives are mining the available sequence data to implement markers and generate increasingly more extensive linkage maps. The number of shrimp genes for which at least some sequence information is now known is in the thousands, rather than the dozens, as was the case just a few years ago. The tools are also in place to refine the selection of candidate aquaculture-relevant genes through the characterization of two key aspects of the function of a gene: its expression and its loss-of-function phenotype. We can now measure the expression of thousands of these genes simultaneously, thanks to progress in transcriptomic methodologies, although much effort is still necessary within the community to meet the analytical challenges involved. Remarkably, it is now possible to block the expression of a gene in a targeted manner in vivo (using RNAi) a task that just a few years ago seemed only feasible in a few well-established animal models. A significant step forward in the control of viral diseases, one of the most important constraints to shrimp aquaculture, seems just around the corner. It is now possible to afford almost complete protection from highly pathogenic viruses by delivering dsRNA molecules that are produced by relatively simple methods.

So, what is the future of shrimp genetics and genomics as it relates to aquaculture? We propose that future success in this area is closely linked to the ability of the community to work cooperatively, sharing information and resources in benefit of the overall advancement of the science. The relative lack of unified efforts and multilab resources such as EST databases, microarray platforms, and library repositories, are indicators of the need to strengthen the ties among shrimp researchers. The challenges imposed by the sheer magnitude of genomic projects will likely be met only by a unified community, with a demonstrated capacity to gain the most out of shared resources. Such an evolution of attitudes will likely make it feasible to support a full-genome sequencing project for a Penaeid shrimp in the near future.

\section{References}

Amparyup, P., W. Charoensapsri and A. Tassanakajon. 2009. Two prophenoloxidases are important for the survival of Vibrio harveyi challenged shrimp Penaeus monodon. Dev Comp Immunol 33(2): 247-56.

Ankra-Badu, G. A., D. Pomp, D. Shriner, D. B. Allison and N. Yi. 2009. Genetic influences on growth and body composition in mice: multilocus interactions. Int J Obes (Lond) 33(1): 89-95.

Assavalapsakul, W., D. R. Smith and S. Panyim. 2006. Identification and characterization of a Penaeus monodon lymphoid cell-expressed receptor for the yellow head virus. J Virol 80(1): 262-9.

Brockmann, G. A., J. Kratzsch, C. S. Haley, U. Renne, M. Schwerin and S. Karle. 2000. Single QTL effects, epistasis, and pleiotropy account for two-thirds of the phenotypic $F(2)$ variance of growth and obesity in DU6i x DBA/2 mice. Genome Res 10(12): 1941-57.

Campbell, T. N. and F. Y. Choy. 2005. RNA interference: past, present and future. Curr Issues Mol Biol 7(1): 1-6. 
Chow, S., W. J. Dougherty and P. A. Sandifer. 1990. Meiotic chromosome complements and nuclear DNA contents of four species of shrimps of the genus Penaeus. J Crustacean Biol 10(1): 29-36.

de la Vega, E., N. A. O'Leary, J. E. Shockey, J. Robalino, C. Payne, C. L. Browdy, G. W. Warr and P. S. Gross. 2008. Anti-lipopolysaccharide factor in Litopenaeus vannamei (LVALF): a broad spectrum antimicrobial peptide essential for shrimp immunity against bacterial and fungal infection. Mol Immunol 45(7): 1916-25.

Dechklar, M., A. Udomkit and S. Panyim. 2008. Characterization of Argonaute cDNA from Penaeus monodon and implication of its role in RNA interference. Biochem Biophys Res Commun 367(4): 768-74.

Diatchenko, L., Y. F. Lau, A. P. Campbell, A. Chenchik, F. Moqadam, B. Huang, S. Lukyanov, K. Lukyanov, N. Gurskaya, E. D. Sverdlov and P. D. Siebert. 1996. Suppression subtractive hybridization: a method for generating differentially regulated or tissue-specific cDNA probes and libraries. Proc Natl Acad Sci U S A 93(12): 6025-30.

Elbashir, S. M., J. Harborth, W. Lendeckel, A. Yalcin, K. Weber and T. Tuschl. 2001. Duplexes of 21-nucleotide RNAs mediate RNA interference in cultured mammalian cells. Nature 411(6836): 494-8.

FAO. 2007. The State of World Fisheries and Aquaculture 2006. FAO Fisheries and Aquaculture Department, Food and Agriculture Organization of The United Nations. Rome, Italy. $180 \mathrm{pp}$.

Fire, A., S. Xu, M. K. Montgomery, S. A. Kostas, S. E. Driver and C. C. Mello. 1998. Potent and specific genetic interference by double-stranded RNA in Caenorhabditis elegans. Nature 391(6669): 806-11.

Garcia, D. K., M. A. Faggart, L. Rhoades, A. A. Alcivar-Warren, J. A. Wyban, W. H. Carr, J. N. Sweeney and K. M. Ebert. 1994. Genetic diversity of cultured Penaeus vannamei shrimp using three molecular genetic techniques. Mol Mar Biol Biotechnol 3(5): 270-80.

Glenn, K. L., L. Grapes, T. Suwanasopee, D. L. Harris, Y. Li, K. Wilson and M. F. Rothschild. 2005. SNP analysis of AMY2 and CTSL genes in Litopenaeus vannamei and Penaeus monodon shrimp. Anim Genet 36(3): 235-6.

Gorbach, D. M., Z.-L. Hu, Z.-Q. Du and M. F. Rothschild. 2009. SNP discovery in Litopenaeus vannamei with a new computational pipeline. Anim Genet 40(1): 106-9.

Gorbach, D. M., Z.-L. Hu, Z.-Q. Du and M. F. Rothschild. submitted. Mining ESTs to determine the usefulness of SNPs across species. Aquaculture.

Han, Y., W. Teng, D. Sun, Y. Du, L. Qiu, X. Xu and W. Li. 2008. Impact of epistasis and QTLxenvironment interaction on the accumulation of seed mass of soybean ( Glycine max L. Merr.). Genet Res 90(6): 481-91.

Huang, X. and A. Madan. 1999. CAP3: A DNA sequence assembly program. Genome Res 9(9): 868-77.

Johnson, K. N., M. C. van Hulten and A. C. Barnes. 2008. "Vaccination" of shrimp against viral pathogens: phenomenology and underlying mechanisms. Vaccine 26(38): 4885-92.

Liang, P. and A. B. Pardee. 1992. Differential display of eukaryotic messenger RNA by means of the polymerase chain reaction. Science 257(5072): 967-71.

Lightner, D. V., B. T. Poulos, K. F. Tang-Nelson, C. R. Pantoja, L. M. Nunan, S. A. Navarro, R. M. Redman and L. L. Mohney. 2006. Application of molecular diagnostic methods to penaeid shrimp diseases: advances of the past 10 years for control of viral diseases in farmed shrimp. Dev Biol (Basel) 126: 117-22; discussion 325-6.

Lightner, D. V. and R. M. Redman. 1998. Shrimp diseases and current diagnostic methods. Aquaculture 164: 201-220.

Liu, G., J. Yang, H. Xu and J. Zhu. 2007. Influence of epistasis and QTL $x$ environment interaction on heading date of rice (Oryza sativa L.). J Genet Genomics 34(7): 608-15. 
Maneeruttanarungroj, C., S. Pongsomboon, S. Wuthisuthimethavee, S. Klinbunga, K. J. Wilson, J. Swan, Y. Li, V. Whan, K. H. Chu, C. P. Li, J. Tong, K. Glenn, M. Rothschild, D. Jerry and A. Tassanakajon. 2006. Development of polymorphic expressed sequence tagderived microsatellites for the extension of the genetic linkage map of the black tiger shrimp (Penaeus monodon). Anim Genet 37(4): 363-8.

Manichaikul, A., J. Y. Moon, S. Sen, B. S. Yandell and K. W. Broman. 2008. A Model Selection Approach for the Identification of Quantitative Trait Loci in Experimental Crosses, Allowing Epistasis. Genetics.

Meehan, D., Z. Xu, G. Zuniga and A. Alcivar-Warren. 2003. High frequency and large number of polymorphic microsatellites in cultured shrimp, Penaeus (Litopenaeus) vannamei [Crustacea:Decapoda]. Mar Biotechnol (NY) 5(4): 311-30.

Motsinger, A. A., S. L. Lee, G. Mellick and M. D. Ritchie. 2006. GPNN: power studies and applications of a neural network method for detecting gene-gene interactions in studies of human disease. BMC Bioinformatics 7: 39.

Newmark, P. A., P. W. Reddien, F. Cebria and A. Sanchez Alvarado. 2003. Ingestion of bacterially expressed double-stranded RNA inhibits gene expression in planarians. Proc Natl Acad Sci U S A 100 Suppl 1: 11861-5.

O'Connor, M., M. Peifer and W. Bender. 1989. Construction of large DNA segments in Escherichia coli. Science 244(4910): 1307-12.

Perez-Rostro, C. I. and A. M. Ibarra. 2003. Heritabilities and genetic correlations of size traits at harvest size in sexually dimorphic Pacific white shrimp (Litopenaeus vannamei) grown in two environments. Aquaculture Research 34: 1079-1085.

Rinkevich, B. 2005. Marine invertebrate cell cultures: new millennium trends. Mar Biotechnol (NY) 7(5): 429-39.

Ritchie, M. D., B. C. White, J. S. Parker, L. W. Hahn and J. H. Moore. 2003. Optimization of neural network architecture using genetic programming improves detection and modeling of gene-gene interactions in studies of human diseases. BMC Bioinformatics 4: 28.

Robalino, J., T. Bartlett, E. Shepard, S. Prior, G. Jaramillo, E. Scura, R. W. Chapman, P. S. Gross, C. L. Browdy and G. W. Warr. 2005. Double-stranded RNA induces sequencespecific antiviral silencing in addition to nonspecific immunity in a marine shrimp: convergence of RNA interference and innate immunity in the invertebrate antiviral response? J Virol 79(21): 13561-71.

Robalino, J., C. L. Browdy, S. Prior, A. Metz, P. Parnell, P. Gross and G. Warr. 2004. Induction of antiviral immunity by double-stranded RNA in a marine invertebrate. $\mathrm{J}$ Virol 78(19): 10442-8.

Sarathi, M., M. C. Simon, V. P. Ahmed, S. R. Kumar and A. S. Hameed. 2008a. Silencing VP28 gene of white spot syndrome virus of shrimp by bacterially expressed dsRNA. Mar Biotechnol (NY) 10(2): 198-206.

Sarathi, M., M. C. Simon, C. Venkatesan and A. S. Hameed. 2008b. Oral administration of bacterially expressed VP28dsRNA to protect Penaeus monodon from white spot syndrome virus. Mar Biotechnol (NY) 10(3): 242-9.

Shekhar, M. S. and Y. Lu. 2009. Application of Nucleic-acid-based Therapeutics for Viral Infections in Shrimp Aquaculture. Mar Biotechnol (NY) 11(1): 1-9.

Shockey, J. E., N. A. O'Leary, E. de la Vega, C. L. Browdy, J. E. Baatz and P. S. Gross. 2008. The role of crustins in Litopenaeus vannamei in response to infection with shrimp pathogens: An in vivo approach. Dev Comp Immunol.

Soares, M. B., M. F. Bonaldo, P. Jelene, L. Su, L. Lawton and A. Efstratiadis. 1994. Construction and characterization of a normalized cDNA library. Proc Natl Acad Sci U S A 91(20): 9228-32. 
Staelens, J., D. Rombaut, I. Vercauteren, B. Argue, J. Benzie and M. Vuylsteke. 2008. High-density linkage maps and sex-linked markers for the black tiger shrimp (Penaeus monodon). Genetics 179(2): 917-25.

Su, J., D. T. Oanh, R. E. Lyons, L. Leeton, M. C. van Hulten, S. H. Tan, L. Song, K. V. Rajendran and P. J. Walker. 2008. A key gene of the RNA interference pathway in the black tiger shrimp, Penaeus monodon: identification and functional characterisation of Dicer-1. Fish Shellfish Immunol 24(2): 223-33.

Tenllado, F., B. Martinez-Garcia, M. Vargas and J. R. Diaz-Ruiz. 2003. Crude extracts of bacterially expressed dsRNA can be used to protect plants against virus infections. BMC Biotechnol 3: 3.

Timmons, L. and A. Fire. 1998. Specific interference by ingested dsRNA. Nature 395(6705): 854.

Tirasophon, W., Y. Roshorm and S. Panyim. 2005. Silencing of yellow head virus replication in penaeid shrimp cells by dsRNA. Biochem Biophys Res Commun 334(1): 102-7.

Treerattrakool, S., S. Panyim, S. M. Chan, B. Withyachumnarnkul and A. Udomkit. 2008. Molecular characterization of gonad-inhibiting hormone of Penaeus monodon and elucidation of its inhibitory role in vitellogenin expression by RNA interference. FEBS J 275(5): 970-80.

Unajak, S., V. Boonsaeng and S. Jitrapakdee. 2006. Isolation and characterization of cDNA encoding Argonaute, a component of RNA silencing in shrimp (Penaeus monodon). Comp Biochem Physiol B Biochem Mol Biol 145(2): 179-87.

Walshe, D. P., S. M. Lehane, M. J. Lehane and L. R. Haines. 2008. Prolonged gene knockdown in the tsetse fly Glossina by feeding double stranded RNA. Insect Mol Biol.

Warr, G. W., J. S. Almeida and R. W. Chapman. 2007. Computational challenges for the analysis of large datasets related to aquatic environmental genomics. 413-426 J. Liu (ed). Aquaculture Genome Technologies. Blackwell Publishing. Oxford.

Wilson, K., Y. Li, V. Whan, L. S., K. Byrne, S. Moore, S. Pongsomboon, A. Tassanakajon, G. Rosenberg, E. Ballment, Z. Fayazia, J. Swana, M. Kenwaya and B. J. 2002. Genetic mapping of the black tiger shrimp Penaeus monodon with amplified fragment length polymorphism. Aquaculture 204(3-4): 185-519.

Xu, Z., A. K. Dhar, J. Wyrzykowski and A. Alcivar-Warren. 1999. Identification of abundant and informative microsatellites from shrimp (Penaeus monodon) genome. Anim Genet 30(2): 150-6.

Yu, M., Y. Cheng and M. Rothschild. 2006. SNP analysis of molting related genes in Penaeus monodon and Litopenaeus vannamei shrimp. Arch Tierz, Dummerstorf 49(4): 411-412.

Zeng, D., X. Chen, Y. Li, M. Peng, N. Ma, W. Jiang, C. Yang and M. Li. 2008. Analysis of Hsp70 in Litopenaeus vannamei and detection of SNPs. J Crustacean Biol 28(4): 727-730. Zhang, L., C. Yang, Y. Zhang, L. Li, X. Zhang, Q. Zhang and J. Xiang. 2007. A genetic linkage map of Pacific white shrimp (Litopenaeus vannamei): sex-linked microsatellite markers and high recombination rates. Genetica 131(1): 37-49. 


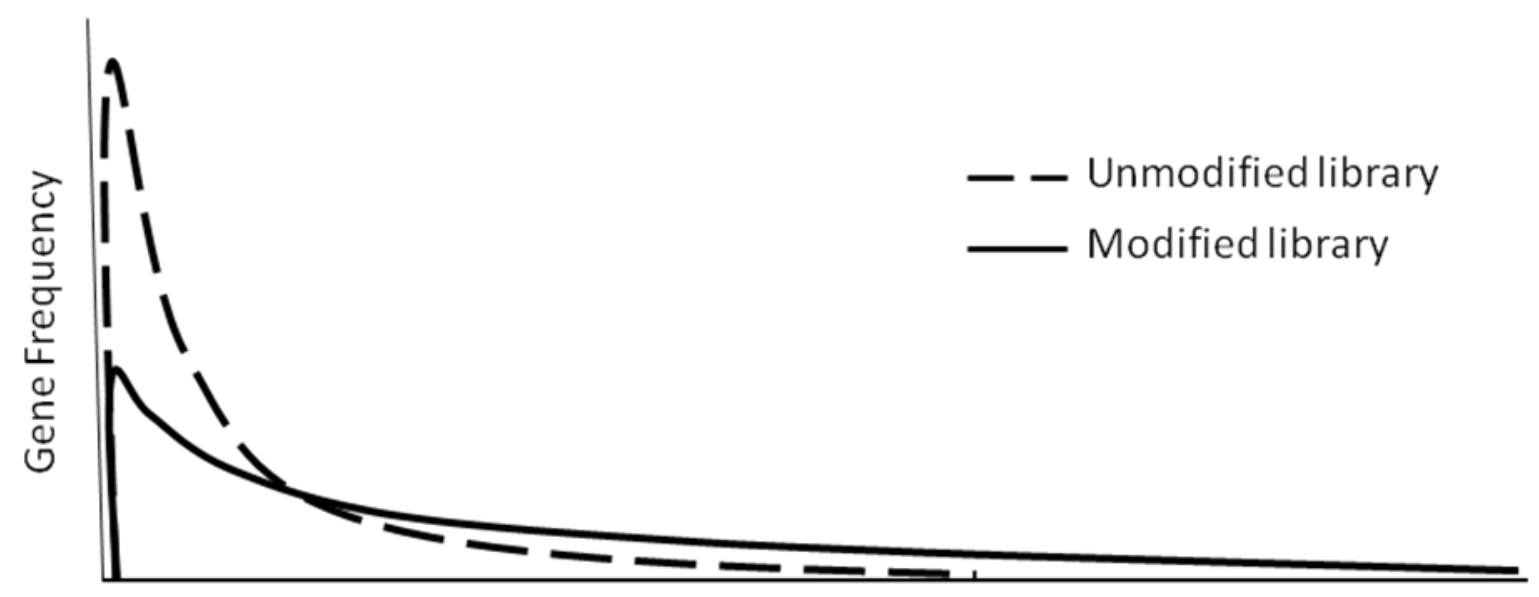

\# Unique Sequences

Figure 1. Expected gene frequency distribution in an unmodified vs a depleted or modified cDNA library. Removing highly redundant gene sequences from a cDNA library results in a better rate of return of unique sequences with the same sequencing effort. 
Table 1. Studies reporting characterization of ESTs in Penaeid shrimp

\begin{tabular}{|c|c|c|c|c|}
\hline Species & $\begin{array}{lr}\text { Tissues } & \text { and } \\
\text { conditions } & \text { under } \\
\text { study } & \end{array}$ & $\begin{array}{l}\text { \#ESTs/uniqu } \\
\text { e sequences }\end{array}$ & Principal findings/genes & References \\
\hline $\mathrm{Pm}$ & Testes & 896/NA & $\begin{array}{l}\text { Discovery of genes involved } \\
\text { in reproductive maturation } \\
\text { and sex determination. } \\
\text { Description of testes } \\
\text { specific genes. }\end{array}$ & $\begin{array}{l}\text { (Leelatanawit et } \\
\text { al. 2009) }\end{array}$ \\
\hline $\mathrm{Pm}$ & $\begin{array}{lr}\text { lymphoid } & \text { organ from } \\
\text { Vibrio } & \text { harveyi } \\
\text { infected } & \text { animals } \\
\text { compared } & \text { to non- } \\
\text { infected } & \text { animals }\end{array}$ & $\begin{array}{l}408 \text { normal; } \\
625 \text { infected/NA }\end{array}$ & $\begin{array}{l}\text { Discovery of genes } \\
\text { differential expressed in } \\
\text { response to bacterial } \\
\text { challenge. Discussion of the } \\
\text { cathepsin family (L and B). } \\
\text { pmonodon.biotec.or.th/home.j } \\
\text { sp }\end{array}$ & $\begin{array}{l}\text { (Pongsomboon et al. } \\
2008 \mathrm{~b} \text { ) }\end{array}$ \\
\hline $\mathrm{Pm}$ & vitellogenic ovaries & $1051 / 559$ & $\begin{array}{l}\text { Identification } \text { of } \text { sex- } \\
\text { related genes. } \\
\text { analysis of Further } \\
\text { protein (CBX) which is } \\
\text { preferentially expressed in } \\
\text { ovaries. }\end{array}$ & $\begin{array}{l}\text { (Preechaphol et al. } \\
2007 \text { ) }\end{array}$ \\
\hline $\mathrm{Pm}$ & $\begin{array}{l}\text { Postlarvae infected } \\
\text { with WSSV }\end{array}$ & $\begin{array}{l}6,671 \\
\text { normal and } \\
7,298 \\
\text { infected/ } \\
9622 \\
\end{array}$ & $\begin{array}{l}\text { Gene discovery in postlarvae } \\
\text { shrimp. } \\
\text { xbio.lifescience.ntu.edu.tw/ } \\
\text { pm/ }\end{array}$ & (Leu et al. 2007) \\
\hline $\mathrm{Pm}$ & $\begin{array}{l}\text { eyestalk, } \\
\text { hepatopancrease, } \\
\text { haematopoietic } \\
\text { tissue, haemocyte, } \\
\text { lymphoid organ, and } \\
\text { ovary from normal, } \\
\text { heat stressed, WSSV, } \\
\text { YHV, and V. harveyi } \\
\text { infected shrimp }\end{array}$ & $10100 / 4845$ & $\begin{array}{l}\text { Large scale gene discovery, } \\
\text { Go analysis } \\
\text { pmodon.biotec.or.th }\end{array}$ & $\begin{array}{l}\text { (Tassanakajon et } \\
\text { al. 2006) }\end{array}$ \\
\hline $\mathrm{Pm}$ & $\begin{array}{l}\text { Hemocytes from Vibrio } \\
\text { harveyi infected } \\
\text { animals compared to } \\
\text { non-infected animals }\end{array}$ & $1062 / \mathrm{NA}$ & $\begin{array}{l}\text { Immune gene discovery with a } \\
\text { focus on antimicrobial } \\
\text { peptides. }\end{array}$ & $\begin{array}{l}\text { (Supungul et } \text { al. } \\
2004 \text { ) }\end{array}$ \\
\hline FC & cephalothorax & $10446 / \mathrm{NA}$ & $\begin{array}{ll}\text { Immune } & \text { gene } \\
\text { Immune } & \text { genes iscovery. } \\
\text { lectins, serine proteases, } \\
\text { serpins, and lysozyme are } \\
\text { discussed. }\end{array}$ & (Shen et al. 2004) \\
\hline $\mathrm{Pm}$ & $\begin{array}{l}\text { Hemocytes from } \\
\text { infected animals }\end{array}$ & $615 / N A$ & 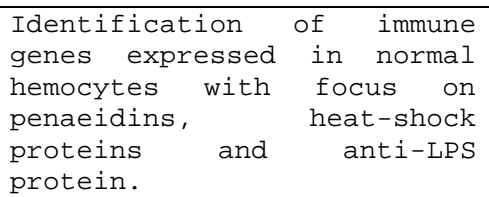 & $\begin{array}{l}\text { (Supungul et } \text { al. } \\
2002 \text { ) }\end{array}$ \\
\hline $\mathrm{Mj}$ & $\begin{array}{l}\text { Hemocytes from WSSV- } \\
\text { infected animals } \\
\text { compared to non- } \\
\text { infected animals }\end{array}$ & $\begin{array}{l}635 \text { normal } \\
370 \\
\text { WSSV/NA }\end{array}$ & Immune gene discovery & $\begin{array}{l}\text { (Rojtinnakorn et } \\
\text { al. 2002) }\end{array}$ \\
\hline LV, Lse & $\begin{array}{ll}\text { hemocytes } & \text { and } \\
\text { hepatopancreas } & \end{array}$ & $2045 / 268$ & Immune gene discovery & (Gross et al. 2001) \\
\hline $\mathrm{Pm}$ & $\begin{array}{l}\text { cephalothorax, } \\
\text { eyestalk, and pleopod } \\
\text { tissue }\end{array}$ & $151 / \mathrm{NA}$ & $\begin{array}{lrr}\text { Gene discovery } & \text { with a } \\
\text { discussion of } & \text { tissue } \\
\text { specific genes. } & \end{array}$ & $\begin{array}{l}\text { (Lehnert et } \quad \text { al. } \\
\text { 1999) }\end{array}$ \\
\hline
\end{tabular}




\begin{tabular}{|c|c|c|c|c|}
\hline LV & $\begin{array}{l}\text { Hemocytes, gills, } \\
\text { hepatopancreas, } \\
\text { lymphoid organ, } \\
\text { eyestalk and ventral } \\
\text { nerve cord }\end{array}$ & $13656 / 7466$ & $\begin{array}{l}\text { Large-scale gene discovery } \\
\text { with focus on genes from } \\
\text { immune related tissues. } \\
\text { WWw.marinegenomics.org }\end{array}$ & $\begin{array}{l}\text { (0'Leary et al. } \\
2006)\end{array}$ \\
\hline LV & Abdominal muscle & $311 / N A$ & $\begin{array}{l}\text { Profile of gene expression } \\
\text { in shrimp muscle tissue. }\end{array}$ & (Cesar et al. 2008) \\
\hline
\end{tabular}

Pm, Penaeus monodon; Fc, Fenneropenaeus chinensis; Mj, Marsupenaeus japonicus; Lv, Litopenaeus vannamei; Lse, Litopenaeus setiferus; NA, not reported 
Table 2. Differential expression cloning studies in Penaeid shrimp

\begin{tabular}{|c|c|c|c|c|c|}
\hline Species & $\begin{array}{lr}\text { Tissues } & \text { and } \\
\text { conditions } & \text { under } \\
\text { study } & \end{array}$ & Method & $\begin{array}{l}\text { \# unique } \\
\text { sequences } \\
\text { identified }\end{array}$ & Principal findings & Reference \\
\hline LS & $\begin{array}{l}\text { Hepatopancreas } \\
\text { from shrimp } \\
\text { experimentally } \\
\text { infected with wSSV } \\
\text { vs. uninfected } \\
\text { shrimp }\end{array}$ & DD & 32 & $\begin{array}{l}\text { One of the earliest } \\
\text { indications of the } \\
\text { challenges of assigning } \\
\text { function to novel } \\
\text { sequences in shrimp }\end{array}$ & $\begin{array}{l}\text { (Astrofsky et } \\
\text { al. 2002) }\end{array}$ \\
\hline $\mathrm{Pm}$ & $\begin{array}{l}\text { Hepatopancreas } \\
\text { from shrimp } \\
\text { surviving a WSSV } \\
\text { outbreak } \quad \text { vs. } \\
\text { uninfected shrimp }\end{array}$ & $\mathrm{DD}$ & NA & $\begin{array}{l}\text { PmAV, a C-type lectin } \\
\text { with apparent antiviral } \\
\text { activity a in a a } \\
\text { heterologous (non shrimp) } \\
\text { virus-host system }\end{array}$ & $\begin{array}{l}(\text { Luo et al. } \\
2003)\end{array}$ \\
\hline $\mathrm{Mj}$ & 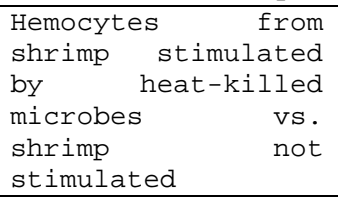 & $\mathrm{SSH}$ & $\begin{array}{l}77 \text { with } \\
\text { homology }\end{array}$ & $\begin{array}{l}\text { Diverse functional groups } \\
\text { of genes appear regulated } \\
\text { by heat-killed microbes, } \\
\text { including } \\
\text { inhibitors }\end{array}$ & $\begin{array}{l}(\mathrm{He} \text { et } \mathrm{al} . \\
2004)\end{array}$ \\
\hline $\mathrm{Mj}$ & $\begin{array}{l}\text { Hemocytes from } \\
\text { shrimp surviving a } \\
\text { WSSV outbreak vs. } \\
\text { uninfected shrimp }\end{array}$ & SSH & 30 & $\begin{array}{lr}\text { Diverse } & \text { functional } \\
\text { categories } & \text { including } \\
\text { chaperones, lectins, and } \\
\text { protease } \\
\text { enriched inhibitors } \\
\text { surviving an outbreak }\end{array}$ & $\begin{array}{l}(\mathrm{He} \text { et } \mathrm{al} . \\
2005)\end{array}$ \\
\hline $\mathrm{Mj}$ & $\begin{array}{l}\text { Hepatopancreas } \\
\text { from shrimp } \\
\text { surviving a WSSV } \\
\text { outbreak } \\
\text { uninfected } \\
\text { shrimp }\end{array}$ & $\mathrm{SSH}$ & 31 & 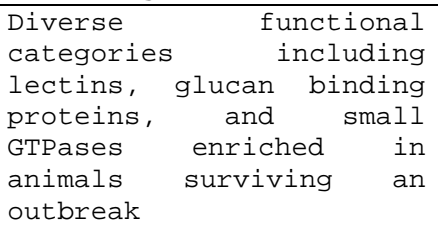 & $\begin{array}{l}(\text { Pan et al. } \\
2005)\end{array}$ \\
\hline LS & $\begin{array}{lr}\text { Hemocytes } & \text { from } \\
\text { animals } & \text { surviving } \\
\text { a } & \text { bacterial } \\
\text { challenge compared } \\
\text { to non-surviving } \\
\text { animals }\end{array}$ & $\mathrm{SSH}$ & 184 & $\begin{array}{lr}\text { Increased } & \text { expression of } \\
\text { several } & \text { antimicrobials } \\
\text { (e.g. } & \text { penaeidin, } \\
\text { lysozyme, cryptdin-like) } \\
\text { co-relating with survival } \\
\text { to bacterial infection }\end{array}$ & $\begin{array}{l}\text { (de Lorgeril } \\
\text { et al. 2005) }\end{array}$ \\
\hline $\mathrm{Pm}$ & $\begin{array}{l}\text { Hemocytes } \quad \text { from } \\
\text { Vibrio } \quad \text { harveyi } \\
\text { infected animals } \\
\text { compared to non- } \\
\text { infected animals }\end{array}$ & $\mathrm{DD}$ & $\begin{array}{l}24 \text { with } \\
\text { homology }\end{array}$ & $\begin{array}{l}\text { Induction of expected } \\
\text { immune effectors (e.g. } \\
\text { lysozyme, } \\
\text { transglutaminase), and of } \\
\text { Argonaute, a gene of the } \\
\text { RNAi pathway }\end{array}$ & $\begin{array}{l}\text { (Somboonwiwat } \\
\text { et al. 2006) }\end{array}$ \\
\hline LV &  & $\mathrm{SSH}$ & $\begin{array}{l}3,231 \text { from } \\
\text { both SSH } \\
\text { and } \\
\text { standard } \\
\text { cDNA } \\
\text { libraries }\end{array}$ & $\begin{array}{l}\text { A wide range of genes } \\
\text { with potential roles in } \\
\text { immunity, } \\
\text { antimicrobials, signaling } \\
\text { factors, transcription } \\
\text { factors, regulators of } \\
\text { apoptosis, were suggested } \\
\text { to be regulated by immune } \\
\text { stimuli }\end{array}$ & $\begin{array}{ll}\text { (Robalino et } & \text { et 2007) } \\
\text { al. }\end{array}$ \\
\hline LV & $\begin{array}{l}\text { Hepatopancreas } \\
\text { from uninfected } \\
\text { members of a } \\
\text { shrimp family } \\
\text { selected based on } \\
\text { its reduced } \\
\text { susceptibility to } \\
\text { WSSV, compared to } \\
\text { a family with high }\end{array}$ & $\mathrm{SSH}$ & $\begin{array}{l}\text { 193, with } \\
40 \text { matches } \\
\text { to known } \\
\text { genes }\end{array}$ & $\begin{array}{l}\text { Diverse functional } \\
\text { categories of genes } \\
\text { suggested to be enriched } \\
\text { in WSSV-resistant family. } \\
\text { These included lysozymes, } \\
\text { cathepsins, lectins, and } \\
\text { other potential } \\
\text { antimicrobials }\end{array}$ & $\begin{array}{l}\text { (Zhao et al. } \\
2007)\end{array}$ \\
\hline
\end{tabular}




\begin{tabular}{|c|c|c|c|c|c|}
\hline & susceptibility & & & & \\
\hline $\mathrm{Pm}$ & $\begin{array}{lr}\text { Hemocytes } & \text { from } \\
\text { shrimp } & \text { subjected } \\
\text { to } & \text { osmotic, } \\
\text { hypoxic, } & \text { or } \\
\text { thermal } & \text { stress, } \\
\text { compared to non- } \\
\text { stressed animals }\end{array}$ & SSH & $\begin{array}{l}176, \text { with } \\
58 \text { matches } \\
\text { to known } \\
\text { genes }\end{array}$ & $\begin{array}{l}\text { Some known immune factors } \\
\text { and, strikingly, many } \\
\text { retrotransposon-related } \\
\text { sequences are regulated } \\
\text { during abiotic stress }\end{array}$ & $\begin{array}{l}\text { (de la Vega } \\
\text { et al. 2007a) }\end{array}$ \\
\hline $\mathrm{Me}$ & $\begin{array}{l}\text { Hepatopancreas } \\
\text { from shrimp at } \\
\text { different stages } \\
\text { of } \\
\text { development }\end{array}$ & DD & $\begin{array}{l}15 \text { clones } \\
\text { with } \\
\text { homology }\end{array}$ & $\begin{array}{l}\text { Vitellogenin and some } \\
\text { functionally diverse } \\
\text { enzymes regulated during } \\
\text { ovarian maturation }\end{array}$ & $\begin{array}{l}\text { (Wong et al. } \\
2008 \text { ) }\end{array}$ \\
\hline $\mathrm{Pm}$ & $\begin{array}{lr}\text { Testes } & \text { from } \\
\text { broodstock } & \text { vs } \\
\text { juvenile shrimp } & \\
\end{array}$ & SSH & $\begin{array}{l}80 \text { with } \\
\text { homology }\end{array}$ & $\begin{array}{l}\text { Discovery of a progestin } \\
\text { receptor } \\
\text { component } 1 \text { gene }\end{array}$ & $\begin{array}{l}\text { (Leelatanawit } \\
\text { et al. 2008) }\end{array}$ \\
\hline
\end{tabular}

Ls, Litopenaeus stylirostris; Pm, Penaeus monodon; Mj, Marsupenaeus japonicus; Lv, Litopenaeus vannamei; Me, Metapenaeus ensis; DD, differential display; SSH, suppression subtractive hybridization; NA, not reported 
Table 3. Microarray studies in Penaeid shrimp

\begin{tabular}{|c|c|c|c|c|}
\hline Species & $\begin{array}{l}\text { Estimated gene } \\
\text { content } \\
\text { (unique } \\
\text { sequences) }\end{array}$ & $\begin{array}{l}\text { Tissue and conditions } \\
\text { studied }\end{array}$ & Principal findings & Reference \\
\hline LS & 84 & $\begin{array}{l}\text { Hepatopancreas from } \\
\text { shrimp experimentally } \\
\text { infected with wSS vs } \\
\text { uninfected shrimp }\end{array}$ & $\begin{array}{lr}\text { Several } & \text { potential } \\
\text { pattern } & \text { recognition } \\
\text { proteins, such as } \\
\text { lectins and LPS/glucan } \\
\text { binding protein, induced } \\
\text { by WSS }\end{array}$ & $\begin{array}{l}\text { (Dhar et al. } \\
2003 \text { ) }\end{array}$ \\
\hline FC & $\begin{array}{lr}1,578 & \text { unique } \\
\text { cDNAs } & \text { plus } \\
1,536 & \text { SSH } \\
\text { clones } & \end{array}$ & $\begin{array}{l}\text { Whole cephalothorax } \\
\text { from shrimp } \\
\text { experimentally } \\
\text { infected with wSSv vs } \\
\text { uninfected shrimp, } \\
\text { and from naturally } \\
\text { infected shrimp vs } \\
\text { uninfected wild } \\
\text { animals }\end{array}$ & $\begin{array}{l}\text { Diverse groups of genes } \\
\text { regulated during } \\
\text { experimental and natural } \\
\text { WSSV infection, } \\
\text { including chaperones and } \\
\text { genes involved in } \\
\text { metabolism and cell } \\
\text { structure }\end{array}$ & $\begin{array}{l}\text { (Wang et al. } \\
2006 \text { ) }\end{array}$ \\
\hline LV & 2,469 & $\begin{array}{l}\text { Hepatopancreas from } \\
\text { shrimp experimentally } \\
\text { infected with WSSV vs } \\
\text { uninfected shrimp }\end{array}$ & $\begin{array}{l}\text { Induction of some known } \\
\text { antimicrobials and } \\
\text { repression of oxidative } \\
\text { stress genes and of the } \\
\text { immune transcription } \\
\text { factor STAT }\end{array}$ & $\begin{array}{l}\text { (Robalino et } \\
\text { al. 2007) }\end{array}$ \\
\hline $\mathrm{Pm}$ & NA & $\begin{array}{l}\text { Hemocytes from shrimp } \\
\text { exposed to either } \\
\text { osmotic, hypoxic, or } \\
\text { thermal stress }\end{array}$ & $\begin{array}{l}\text { A complex response to } \\
\text { abiotic stress, which } \\
\text { included regulation of } \\
\text { known immune factors } \\
\text { (e.g. crustin, lysozyme, } \\
\text { transglutaminase), as } \\
\text { well as changes in mRNAs } \\
\text { corresponding } \\
\text { retrotransposons }\end{array}$ & $\begin{array}{ll}\text { (de la } & \text { Vega } \\
\text { et } & \text { al. } \\
2007 b) & \end{array}$ \\
\hline $\mathrm{Pm}$ & 2,028 & $\begin{array}{lcr}\text { Hemocytes } & \text { from } & \text { YHV } \\
\text { infected shrimp } & \text { vs } \\
\text { mock infected animals }\end{array}$ & $\begin{array}{l}\text { Known immune genes with } \\
\text { complex patterns of } \\
\text { temporal regulation. } \\
\text { Cathepsin L highly } \\
\text { induced in YHV infected } \\
\text { hemocytes }\end{array}$ & $\begin{array}{l}\text { (Pongsomboon } \\
\text { et al. } \\
2008 \text { a) }\end{array}$ \\
\hline $\mathrm{Mj}$ & 2,036 & $\begin{array}{lr}\text { Hemocytes } & \text { from } \\
\text { peptidoglycan } & \\
\text { stimulated shrimp vs } \\
\text { animals } & \text { not } \\
\text { stimulated } & \end{array}$ & $\begin{array}{lr}\text { Known immune factors } \\
\text { such as antimicrobial } \\
\text { proteins respon to } \\
\text { peptidoglycan } \\
\text { stimulation }\end{array}$ & $\begin{array}{l}\text { (Fagutao et } \\
\text { al.2008) }\end{array}$ \\
\hline FC & 3,114 elements & $\begin{array}{l}\text { Hepatopancreas, } \\
\text { hemocytes, gills, and } \\
\text { lymphoid organ from } \\
\text { shrimp infected with } \\
\text { WSSV vs } \\
\text { infected, and from } \\
\text { animals stimulated } \\
\text { with heat-killed } \\
\text { Vibrio anguillarum vs } \\
\text { mock stimulated }\end{array}$ & $\begin{array}{l}\text { Very } \\
\text { dunctionally } \\
\text { diverse groups of genes } \\
\text { responsive to either } \\
\text { immune stimulus, but } \\
\text { also an overlapping } \\
\text { response was observed }\end{array}$ & $\begin{array}{l}\text { (Wang et al. } \\
2008 \mathrm{a})\end{array}$ \\
\hline
\end{tabular}

Ls, Litopenaeus stylirostris; Fc, Fenneropenaeus chinensis; Lv, Litopenaeus vannamei; Pm, Penaeus monodon; Mj, Marsupenaeus japonicus; NA, not reported 
Table 4. RNAi-based experiments in Penaeid shrimp

\begin{tabular}{|c|c|c|c|c|}
\hline Species & Target gene & $\begin{array}{l}\text { RNAi-based } \\
\text { application }\end{array}$ & Phenotype & References \\
\hline \multicolumn{5}{|c|}{ Shrimp gene physiological function studies } \\
\hline $\mathrm{Pm}$ & Argonaute (Pem-AGO) & $\begin{array}{l}\text { dsRNA } \\
\text { transfection into } \\
\text { Oka cells }\end{array}$ & $\begin{array}{l}\text { impaired } \\
\text { ability }\end{array}$ & $\begin{array}{l}\text { (Dechklar } \\
\text { et al. } \\
\text { 2008) }\end{array}$ \\
\hline LV & $\begin{array}{l}\text { putative farnesoic acid } \\
\text { 0-methyltransferase } \\
\text { (LvFAMeT) }\end{array}$ & $\begin{array}{l}\text { dsRNA } \\
\text { injection into the } \\
5^{\text {th }} \text { pereiopod }\end{array}$ & $\begin{array}{l}\text { role in molting } \\
\text { lethal phenotype } \\
\text { induced }\end{array}$ & $\begin{array}{l}\text { (Hui et } \\
\text { al. 2008) }\end{array}$ \\
\hline Lsc & $\begin{array}{l}\text { crustacean hyperglycemic } \\
\text { hormone }(\mathrm{CHH})\end{array}$ & $\begin{array}{ll}\text { dsRNA } & \\
\text { injection } & \text { into } \\
\text { abdominal } & \text { body } \\
\text { cavity } & \end{array}$ & $\begin{array}{l}\text { decrease } \\
\text { hemolymph } \quad \text { in } \\
\text { levels }\end{array}$ & $\begin{array}{l}\text { (Lugo et } \\
\text { al. 2006) }\end{array}$ \\
\hline LV & $\begin{array}{l}\text { putative ion transport } \\
\text { peptide (LVITP) }\end{array}$ & $\begin{array}{l}\text { dsRNA } \\
\text { injection into the } \\
5^{\text {th }} \text { pereiopod }\end{array}$ & $\begin{array}{l}\text { role in } \quad \text { osmo- } \\
\text { regulatory function } \\
\text { lethal } \\
\text { induced }\end{array}$ & $\begin{array}{l}\text { (Tiu et } \\
\text { al. 2007) }\end{array}$ \\
\hline LV & Hemocyanin & $\begin{array}{l}\text { dsRNA/siRNA } \\
\text { intramuscular } \\
\text { injection }\end{array}$ & $\begin{array}{lr}\text { - reduction } & \text { in } \\
\text { hemocyanin } & \text { mRNA } \\
\text { levels after dsRNA } \\
\text { injection } \\
\text { - siRNAs failed to } \\
\text { induce } \\
\text { interference }\end{array}$ & $\begin{array}{l}\text { (Robalino } \\
\text { et al. } \\
\text { 2005) }\end{array}$ \\
\hline LV & CDP (CUB domain protein) & $\begin{array}{l}\text { dsRNA } \\
\text { intramuscular } \\
\text { injection }\end{array}$ & $\begin{array}{l}\text { reduction in CDP } \\
\text { mRNA levels }\end{array}$ & $\begin{array}{l}\text { (Robalino } \\
\text { et al. } \\
2005)\end{array}$ \\
\hline $\mathrm{Me}$ & $\begin{array}{l}\text { Molt-inhibiting hormone } \\
\text { (MeMIH-B) }\end{array}$ & $\begin{array}{l}\text { dsRNA } \\
\text { injection into the } \\
\text { pereiopod }\end{array}$ & $\begin{array}{l}\text { gonad-stimulatory } \\
\text { function }\end{array}$ & $\begin{array}{l}\text { (Tiu and } \\
\text { Chan } \\
2007) \\
\end{array}$ \\
\hline Pm & $\begin{array}{l}\text { Gonad-inhibiting hormone } \\
\text { (Pem-GIH) }\end{array}$ & $\begin{array}{l}\text { dsRNA } \\
-\quad \text { injection into } \\
\text { the pereiopod } \\
-\quad \text { incubation in } \\
\text { explant culture }\end{array}$ & $\begin{array}{l}\text { gonad-inhibitory } \\
\text { function }\end{array}$ & $\begin{array}{l}\text { (Treeratt } \\
\text { rakool et } \\
\text { al. 2008) }\end{array}$ \\
\hline $\mathrm{Pm}$ & $\begin{array}{l}\text { Vitellogenin receptor } \\
\text { (VgR) }\end{array}$ & $\begin{array}{l}\text { dsRNA } \\
\text { intramuscular } \\
\text { injection }\end{array}$ & $\begin{array}{lr}\text { role in } & \text { the } \\
\text { processing } & \text { of } \\
\text { vitellogenin } & \\
\end{array}$ & $\begin{array}{l}\text { (Tiu et } \\
\text { al. 2008) }\end{array}$ \\
\hline \multicolumn{5}{|c|}{ Host-pathogen interaction studies } \\
\hline LV & $\begin{array}{l}\text { Anti-lipopolysaccharide } \\
\text { factor (LVALF) }\end{array}$ & $\begin{array}{l}\text { dsRNA } \\
\text { intramuscular } \\
\text { injection }\end{array}$ & $\begin{array}{l}\text { role in immune } \\
\text { function against } \\
\text { bacterial and fungal } \\
\text { infections }\end{array}$ & $\begin{array}{l}\text { (de la } \\
\text { Vega et } \\
\text { al. 2008) }\end{array}$ \\
\hline LV & Crustin (LVABP1) & $\begin{array}{l}\text { dsRNA } \\
\text { intramuscular } \\
\text { injection }\end{array}$ & $\begin{array}{l}\text { role in anti- } \\
\text { bacterial response }\end{array}$ & $\begin{array}{l}\text { (Shockey } \\
\text { et al. } \\
2008)\end{array}$ \\
\hline Pm & $\begin{array}{l}\text { Prophenoloxidases } \\
\text { (PmproP01, 2) }\end{array}$ & $\begin{array}{l}\text { dsRNA } \\
\text { intramuscular } \\
\text { injection }\end{array}$ & $\begin{array}{l}\text { role in anti- } \\
\text { bacterial response }\end{array}$ & $\begin{array}{l}\text { (Amparyup } \\
\text { et al. } \\
2009 \text { ) }\end{array}$ \\
\hline Mj & Rab-GTPase (PjRab) & $\begin{array}{l}\text { SiRNA } \\
\text { intramuscular } \\
\text { injection }\end{array}$ & $\begin{array}{l}\text { increased } \\
\text { replication }\end{array}$ & $\begin{array}{c}(\text { Wu et } \\
\text { al. 2008) }\end{array}$ \\
\hline Pm & $\begin{array}{l}\text { Small GTPase protein } \\
(\text { PmRab7) }\end{array}$ & $\begin{array}{l}\text { dsRNA } \\
\text { intramuscular } \\
\text { injection }\end{array}$ & $\begin{array}{l}\text { role in the } \\
\text { endosomal } \\
\text { trafficking pathway }\end{array}$ & $\begin{array}{l}\text { (Ongvarra } \\
\text { sopone et } \\
\text { al. 2008) }\end{array}$ \\
\hline Mj & $\begin{array}{l}\text { - Transglutaminase } \\
\text { (TGase) } \\
\text { - Clotting protein (CP) }\end{array}$ & $\begin{array}{l}\text { dsRNA } \\
\text { intramuscular } \\
\text { injection }\end{array}$ & $\begin{array}{l}\text { role in immune } \\
\text { function against } \\
\text { bacterial and fungal } \\
\text { infections }\end{array}$ & $\begin{array}{l}\text { (Maningas } \\
\text { et al. } \\
2007 \text { ) }\end{array}$ \\
\hline Mj & Caspase (PjCaspase) & $\begin{array}{l}\text { SiRNA } \\
\text { intramuscular } \\
\text { injection }\end{array}$ & $\begin{array}{ll}\text { role in virus- } \\
\text { induced apoptosis }\end{array}$ & $\begin{array}{l}\text { (Wang et } \\
\text { al. } \\
2008 \mathrm{~b} \text { ) }\end{array}$ \\
\hline Mj & $\beta$-integrin & $\begin{array}{l}\text { siRNA } \\
\text { intramuscular } \\
\text { injection }\end{array}$ & $\begin{array}{l}\text { cellular receptor } \\
\text { for WSSV infection. }\end{array}$ & $\begin{array}{c}\text { (Li et } \\
\text { al. 2007) }\end{array}$ \\
\hline LV & $\begin{array}{l}\text { Caspase }-3 \\
(\text { Cap-3) }\end{array}$ & $\begin{array}{l}\text { dsRNA } \\
\text { intramuscular } \\
\text { injection }\end{array}$ & $\begin{array}{l}\text { role in virus- } \\
\text { induced apoptosis }\end{array}$ & $\begin{array}{l}\text { (Rijirava } \\
\text { nich et } \\
\text { al. 2008) }\end{array}$ \\
\hline $\mathrm{Pm}$ & Dicer 1 (Pm Dcr1) & dsRNA & increased & (Su et \\
\hline
\end{tabular}




\begin{tabular}{|c|c|c|c|c|}
\hline & & $\begin{array}{l}\text { intramuscular } \\
\text { injection }\end{array}$ & $\begin{array}{ll}\text { susceptibility } & \text { to } \\
\text { viral infection } & \\
\end{array}$ & al. 2008) \\
\hline $\mathrm{Pm}$ & $\begin{array}{l}\text { YHV binding protein } \\
\text { (pmYRP65) }\end{array}$ & $\begin{array}{l}\text { dsRNA } \\
\text { transfection into } \\
\text { Oka cells }\end{array}$ & $\begin{array}{l}\text { inhibition of YHV } \\
\text { infection }\end{array}$ & $\begin{array}{l}\text { (Assavala } \\
\text { psakul et } \\
\text { al. 2006) }\end{array}$ \\
\hline \multicolumn{5}{|c|}{ RNAi-mediated antiviral silencing } \\
\hline Fc & $\begin{array}{l}\text { - VP28 (WSSV) } \\
\text { - VP281 (WSSV) } \\
\text { - protein kinase coding } \\
\text { gene (WSSV) }\end{array}$ & $\begin{array}{l}\text { dsRNA } \\
\text { intramuscular } \\
\text { injection }\end{array}$ & $\begin{array}{l}\text { higher } \\
\text { rates }\end{array}$ & $\begin{array}{c}(\text { Kim et } \\
\text { al. 20๑7) }\end{array}$ \\
\hline $\mathrm{Pm}$ & $\begin{array}{l}\text { - helicase coding gene } \\
\text { (YHV) } \\
\text { - polymerase coding gene } \\
\text { (YHV) } \\
\text { - protease coding } \\
\text { gene(YHV) } \\
\text { - gp116 (YHV) } \\
\text { - gp64 (YHV) }\end{array}$ & $\begin{array}{l}\text { dsRNA } \\
\text { transfection into } \\
\text { Oka cells }\end{array}$ & $\begin{array}{l}\text { inhibition of } \\
\text { replication }\end{array}$ & $\begin{array}{c}\text { (Tirasoph } \\
\text { on et al. } \\
2005 \text { ) }\end{array}$ \\
\hline $\mathrm{Pm}$ & YHV-protease & $\begin{array}{l}\text { dsRNA } \\
\text { intramuscular } \\
\text { injection }\end{array}$ & $\begin{array}{lr}\text { inhibition of } & \text { YHV } \\
\text { multiplication } & \text { in } \\
\text { infected shrimp } & \\
\end{array}$ & $\begin{array}{l}\text { (Tirasoph } \\
\text { on et al. } \\
2007 \text { ) }\end{array}$ \\
\hline $\mathrm{Pm}$ & $\begin{array}{lll}\text { coding region of a } & \text { adiote gene }(\mathrm{YHV})\end{array}$ & $\begin{array}{l}\text { dsRNA } \\
\text { intramuscular } \\
\text { injection }\end{array}$ & $\begin{array}{l}\text { - inhibition of YHV } \\
\text { replication } \\
\text { - protection from } \\
\text { YHV infection } \\
\end{array}$ & $\begin{array}{l}\text { (Yodmuang } \\
\text { et al. } \\
2006 \text { ) }\end{array}$ \\
\hline $\mathrm{Pm}$ & $\begin{array}{l}\text { - Vp28 (WSSV) } \\
\text { - Vp15 (WSSV) }\end{array}$ & $\begin{array}{l}\text { SiRNA } \\
- \text { transfection in } \\
\text { insect cells } \\
-\quad \text { intramuscular } \\
\text { injection }\end{array}$ & $\begin{array}{l}\text { - silencing of } \\
\text { homologous genes in } \\
\text { a heterologous } \\
\text { expression system } \\
\text { - siRNAs failed to } \\
\text { induce sequence- } \\
\text { specific antiviral } \\
\text { immunity }\end{array}$ & $\begin{array}{l}\text { (Westenbe } \\
\text { rg et al. } \\
2005 \text { ) }\end{array}$ \\
\hline Mj & Vp28 (WSSV) & $\begin{array}{l}\text { SiRNA } \\
\text { intramuscular } \\
\text { injection }\end{array}$ & $\begin{array}{l}\text { Reduction in viral } \\
\text { DNA production of } \\
\text { infected animals }\end{array}$ & $\begin{array}{c}(\mathrm{Xu} \text { et } \\
\text { al. 2007) }\end{array}$ \\
\hline LV & Vp19 (WSSV) & $\begin{array}{l}\text { dsRNA/siRNAs } \\
\text { intramuscular } \\
\text { injection }\end{array}$ & $\begin{array}{l}\text { - higher survival } \\
\text { rates after dsRNA } \\
\text { injection } \\
\text { - siRNAs failed to } \\
\text { induce antiviral } \\
\text { immunity }\end{array}$ & $\begin{array}{l}\text { (Robalino } \\
\text { et al. } \\
2005 \text { ) }\end{array}$ \\
\hline LV & \begin{tabular}{ll} 
& DNA polymerase (WSSV) \\
- & \multicolumn{2}{c}{ ribonucleotide } \\
reductase small subunit \\
(WSSV) & \\
$-\quad$ thymidine & kinase \\
(WSSV) & \\
$-\quad$ thymidylate & kinase \\
$($ WSSV)) & \\
- Vp24 (WSSV) & \\
- Vp28 (WSSV) & \\
\end{tabular} & $\begin{array}{l}\text { SiRNA } \\
\text { intramuscular } \\
\text { injection }\end{array}$ & $\begin{array}{l}\text { - inhibition of WSSV } \\
\text { replication } \\
\text { - suppression of } \\
\text { selected WSSV gene } \\
\text { expression } \\
\text { - higher survival } \\
\text { rates }\end{array}$ & $\begin{array}{c}\text { (Wu et } \\
\text { al. 2007) }\end{array}$ \\
\hline LV & $\begin{array}{l}- \\
\text { reductase small subunit } \\
\text { (WSSV) } \\
-\quad \text { DNA polymerase DP } \\
\text { (WSSV) } \\
- \text { ORF WSV252 (WSSV) } \\
- \text { Vp28 (WSV) }\end{array}$ & $\begin{array}{l}\text { dsRNA } \\
\text { intramuscular } \\
\text { injection }\end{array}$ & $\begin{array}{l}\text { protection from wSSV } \\
\text { infection }\end{array}$ & $\begin{array}{l}\text { (Robalino } \\
\text { et al. } \\
2005 \text { ) }\end{array}$ \\
\hline LV & $\begin{array}{l}\text { predicted protease gene } \\
\text { (TSV) }\end{array}$ & $\begin{array}{l}\text { dsRNA } \\
\text { intramuscular } \\
\text { injection }\end{array}$ & $\begin{array}{l}\text { protection from TSV } \\
\text { infection }\end{array}$ & $\begin{array}{l}\text { (Robalino } \\
\text { et al. } \\
\text { 2005) }\end{array}$ \\
\hline $\mathrm{Pm}$ & Vp28 (WSSV) & $\begin{array}{l}\text { bacterially } \\
\text { expressed dsRNA } \\
\text { oral } \\
\text { administration }\end{array}$ & $\begin{array}{l}\text { protection from WSSV } \\
\text { infection }\end{array}$ & $\begin{array}{l}\text { (Sarathi } \\
\text { et al. } \\
2008 b \text { ) }\end{array}$ \\
\hline $\mathrm{Pm}$ & Vp28 (WSSV) & $\begin{array}{l}\text { bacterially } \\
\text { expressed dsRNA } \\
\text { intramuscular } \\
\text { injection }\end{array}$ & $\begin{array}{l}\text { protection from wSSV } \\
\text { infection }\end{array}$ & $\begin{array}{l}\text { (Sarathi } \\
\text { et al. } \\
20 \odot 8 a)\end{array}$ \\
\hline
\end{tabular}


Pm, Penaeus monodon; Lv, Litopenaeus vannamei; Lsc, Litopenaeus schmitti; Me, Metapenaeus ensis; Mj, Marsupenaeus japonicus; Fc, Fenneropenaeus chinensis 


\section{References}

Amparyup, P., W. Charoensapsri and A. Tassanakajon. 2009. Two prophenoloxidases are important for the survival of Vibrio harveyi challenged shrimp Penaeus monodon. Dev Comp Immunol 33(2): 247-56.

Assavalapsakul, W., D. R. Smith and S. Panyim. 2006. Identification and characterization of a Penaeus monodon lymphoid cell-expressed receptor for the yellow head virus. J Virol 80(1): 262-9.

Astrofsky, K. M., M. M. Roux, K. R. Klimpel, J. G. Fox and A. K. Dhar. 2002. Isolation of differentially expressed genes from white spot virus (WSV) infected Pacific blue shrimp (Penaeus stylirostris). Arch Virol 147(9): 1799-812.

Cesar, J. R., B. Zhao and J. Yang. 2008. Analysis of expressed sequence tags from abdominal muscle cDNA library of the pacific white shrimp Litopenaeus vannamei. Animal 2(9): 1377-1383.

de la Vega, E., B. M. Degnan, M. R. Hall and K. J. Wilson. 2007a. Differential expression of immune-related genes and transposable elements in black tiger shrimp (Penaeus monodon) exposed to a range of environmental stressors. Fish Shellfish Immunol 23(5): 1072-88.

de la Vega, E., M. R. Hall, K. J. Wilson, A. Reverter, R. G. Woods and B. M. Degnan. 2007b. Stress-induced gene expression profiling in the black tiger shrimp Penaeus monodon. Physiol Genomics 31(1): 126-38.

de la Vega, E., N. A. O'Leary, J. E. Shockey, J. Robalino, C. Payne, C. L. Browdy, G. W. Warr and P. S. Gross. 2008. Anti-lipopolysaccharide factor in Litopenaeus vannamei (LVALF): a broad spectrum antimicrobial peptide essential for shrimp immunity against bacterial and fungal infection. Mol Immunol 45(7): 1916-25.

de Lorgeril, J., D. Saulnier, M. G. Janech, Y. Gueguen and E. Bachere. 2005. Identification of genes that are differentially expressed in hemocytes of the Pacific blue shrimp (Litopenaeus stylirostris) surviving an infection with Vibrio penaeicida. Physiol Genomics 21(2): 174-83.

Dechklar, M., A. Udomkit and S. Panyim. 2008. Characterization of Argonaute cDNA from Penaeus monodon and implication of its role in RNA interference. Biochem Biophys Res Commun 367(4): 768-74.

Dhar, A. K., A. Dettori, M. M. Roux, K. R. Klimpel and B. Read. 2003. Identification of differentially expressed genes in shrimp (Penaeus stylirostris) infected with White spot syndrome virus by cDNA microarrays. Arch Virol 148(12): 2381-96.

Fagutao, F. F., M. Yasuike, C. M. Caipang, H. Kondo, I. Hirono, Y. Takahashi and T. Aoki. 2008. Gene expression profile of hemocytes of kuruma shrimp, Marsupenaeus japonicus following peptidoglycan stimulation. Mar Biotechnol (NY) 10(6): 731-40.

Gross, P. S., T. C. Bartlett, C. L. Browdy, R. W. Chapman and G. W. Warr. 2001. Immune gene discovery by expressed sequence tag analysis of hemocytes and hepatopancreas in the Pacific White Shrimp, Litopenaeus vannamei, and the Atlantic White Shrimp, L. setiferus. Dev Comp Immunol 25(7): 565-77.

$\mathrm{He}, \mathrm{N}$., H. Liu and X. Xu. 2004. Identification of genes involved in the response of haemocytes of Penaeus japonicus by suppression subtractive hybridization (SSH) following microbial challenge. Fish Shellfish Immunol 17(2): 121-8.

$\mathrm{He}, \mathrm{N}$., Q. Qin and X. Xu. 2005. Differential profile of genes expressed in hemocytes of White Spot Syndrome Virus-resistant shrimp (Penaeus japonicus) by combining suppression subtractive hybridization and differential hybridization. Antiviral Res 66(1): 39-45.

Hui, J. H., S. S. Tobe and S. M. Chan. 2008. Characterization of the putative farnesoic acid Omethyltransferase (LvFAMeT) cDNA from white shrimp, Litopenaeus vannamei: Evidence for its role in molting. Peptides 29(2): 252-60.

Kim, C. S., Z. Kosuke, Y. K. Nam, S. K. Kim and K. H. Kim. 2007. Protection of shrimp (Penaeus chinensis) against white spot syndrome virus (WSSV) challenge by double-stranded RNA. Fish Shellfish Immunol 23(1): 242-6.

Leelatanawit, R., S. Klinbunga, T. Aoki, I. Hirono, R. Valyasevi and P. Menasveta. 2008. Suppression subtractive hybridization (SSH) for isolation and characterization of genes related to testicular development in the giant tiger shrimp Penaeus monodon. BMB Rep 41(11): 796-802.

Leelatanawit, R., K. Sittikankeaw, P. Yocawibun, S. Klinbunga, S. Roytrakul, T. Aoki, I. Hirono and P. Menasveta. 2009. Identification, characterization and expression of sex-related genes in testes 
of the giant tiger shrimp Penaeus monodon. Comp Biochem Physiol A Mol Integr Physiol 152(1): 66-76.

Lehnert, S. A., K. J. Wilson, K. Byrne and S. S. Moore. 1999. Tissue-Specific Expressed Sequence Tags from the Black Tiger Shrimp Penaeus monodon. Mar Biotechnol (NY) 1(5): 465-0476.

Leu, J. H., C. C. Chang, J. L. Wu, C. W. Hsu, I. Hirono, T. Aoki, H. F. Juan, C. F. Lo, G. H. Kou and H. C. Huang. 2007. Comparative analysis of differentially expressed genes in normal and white spot syndrome virus infected Penaeus monodon. BMC Genomics 8: 120.

Li, D. F., M. C. Zhang, H. J. Yang, Y. B. Zhu and X. Xu. 2007. Beta-integrin mediates WSSV infection. Virology 368(1): 122-32.

Lugo, J. M., Y. Morera, T. Rodriguez, A. Huberman, L. Ramos and M. P. Estrada. 2006. Molecular cloning and characterization of the crustacean hyperglycemic hormone cDNA from Litopenaeus schmitti. Functional analysis by double-stranded RNA interference technique. FEBS J 273(24): 5669-77.

Luo, T., X. Zhang, Z. Shao and X. Xu. 2003. PmAV, a novel gene involved in virus resistance of shrimp Penaeus monodon. FEBS Lett 551(1-3): 53-7.

Maningas, M. B., H. Kondo, I. Hirono, T. Saito-Taki and T. Aoki. 2007. Essential function of transglutaminase and clotting protein in shrimp immunity. Mol Immunol.

O'Leary, N. A., H. F. Trent, III, J. Robalino, M. E. T. Peck, D. J. McKillen and P. S. Gross. 2006. Analysis of multiple tissue-specific cDNA libraries from the Pacific whiteleg shrimp, Litopenaeus vannamei. Integrative and Comparative Biology 46(6): 931-939.

Ongvarrasopone, C., M. Chanasakulniyom, K. Sritunyalucksana and S. Panyim. 2008. Suppression of PmRab7 by dsRNA inhibits WSSV or YHV infection in shrimp. Mar Biotechnol (NY) 10(4): 37481.

Pan, D., N. He, Z. Yang, H. Liu and X. Xu. 2005. Differential gene expression profile in hepatopancreas of WSSV-resistant shrimp (Penaeus japonicus) by suppression subtractive hybridization. Dev Comp Immunol 29(2): 103-12.

Pongsomboon, S., S. Tang, S. Boonda, T. Aoki, I. Hirono, M. Yasuike and A. Tassanakajon. 2008a. Differentially expressed genes in Penaeus monodon hemocytes following infection with yellow head virus. BMB Rep 41(9): 670-7.

Pongsomboon, S., R. Wongpanya, S. Tang, A. Chalorsrikul and A. Tassanakajon. 2008b. Abundantly expressed transcripts in the lymphoid organ of the black tiger shrimp, Penaeus monodon, and their implication in immune function. Fish Shellfish Immunol 25(5): 485-93.

Preechaphol, R., R. Leelatanawit, K. Sittikankeaw, S. Klinbunga, B. Khamnamtong, N. Puanglarp and P. Menasveta. 2007. Expressed sequence tag analysis for identification and characterization of sex-related genes in the giant tiger shrimp Penaeus monodon. J Biochem Mol Biol 40(4): 501-10.

Rijiravanich, A., C. L. Browdy and B. Withyachumnarnkul. 2008. Knocking down caspase-3 by RNAi reduces mortality in Pacific white shrimp Penaeus (Litopenaeus) vannamei challenged with a low dose of white-spot syndrome virus. Fish Shellfish Immunol 24(3): 308-13.

Robalino, J., J. S. Almeida, D. McKillen, J. Colglazier, H. F. Trent, 3rd, Y. A. Chen, M. E. Peck, C. L. Browdy, R. W. Chapman, G. W. Warr and P. S. Gross. 2007. Insights into the immune transcriptome of the shrimp Litopenaeus vannamei: tissue-specific expression profiles and transcriptomic responses to immune challenge. Physiol Genomics 29(1): 44-56.

Robalino, J., T. Bartlett, E. Shepard, S. Prior, G. Jaramillo, E. Scura, R. W. Chapman, P. S. Gross, C. L. Browdy and G. W. Warr. 2005. Double-stranded RNA induces sequence-specific antiviral silencing in addition to nonspecific immunity in a marine shrimp: convergence of RNA interference and innate immunity in the invertebrate antiviral response? J Virol 79(21): 13561-71.

Rojtinnakorn, J., I. Hirono, T. Itami, Y. Takahashi and T. Aoki. 2002. Gene expression in haemocytes of kuruma prawn, Penaeus japonicus, in response to infection with WSSV by EST approach. Fish Shellfish Immunol 13(1): 69-83.

Sarathi, M., M. C. Simon, V. P. Ahmed, S. R. Kumar and A. S. Hameed. 2008a. Silencing VP28 gene of white spot syndrome virus of shrimp by bacterially expressed dsRNA. Mar Biotechnol (NY) 10(2): 198-206.

Sarathi, M., M. C. Simon, C. Venkatesan and A. S. Hameed. 2008b. Oral administration of bacterially expressed VP28dsRNA to protect Penaeus monodon from white spot syndrome virus. Mar Biotechnol (NY) 10(3): 242-9. 
Shen, Y. Q., J. H. Xiang, B. Wang, F. H. Li and W. Tong. 2004. Discovery of immune related factors in Fenneropenaeus chinensis by annotation of ESTs. Progress in Natural Science 14(1): 47-54.

Shockey, J. E., N. A. O'Leary, E. de la Vega, C. L. Browdy, J. E. Baatz and P. S. Gross. 2008. The role of crustins in Litopenaeus vannamei in response to infection with shrimp pathogens: An in vivo approach. Dev Comp Immunol.

Somboonwiwat, K., P. Supungul, V. Rimphanitchayakit, T. Aoki, I. Hirono and A. Tassanakajon. 2006. Differentially expressed genes in hemocytes of Vibrio harveyi-challenged shrimp Penaeus monodon. J Biochem Mol Biol 39(1): 26-36.

Su, J., D. T. Oanh, R. E. Lyons, L. Leeton, M. C. van Hulten, S. H. Tan, L. Song, K. V. Rajendran and P. J. Walker. 2008. A key gene of the RNA interference pathway in the black tiger shrimp, Penaeus monodon: identification and functional characterisation of Dicer-1. Fish Shellfish Immunol 24(2): 223-33.

Supungul, P., S. Klinbunga, R. Pichyangkura, I. Hirono, T. Aoki and A. Tassanakajon. 2004. Antimicrobial peptides discovered in the black tiger shrimp Penaeus monodon using the EST approach. Dis Aquat Organ 61(1-2): 123-35.

Supungul, P., S. Klinbunga, R. Pichyangkura, S. Jitrapakdee, I. Hirono, T. Aoki and A. Tassanakajon. 2002. Identification of immune-related genes in hemocytes of black tiger shrimp (Penaeus monodon). Mar Biotechnol (NY) 4(5): 487-94.

Tassanakajon, A., S. Klinbunga, N. Paunglarp, V. Rimphanitchayakit, A. Udomkit, S. Jitrapakdee, K. Sritunyalucksana, A. Phongdara, S. Pongsomboon, P. Supungul, S. Tang, K. Kuphanumart, R. Pichyangkura and C. Lursinsap. 2006. Penaeus monodon gene discovery project: the generation of an EST collection and establishment of a database. Gene 384: 104-12.

Tirasophon, W., Y. Roshorm and S. Panyim. 2005. Silencing of yellow head virus replication in penaeid shrimp cells by dsRNA. Biochem Biophys Res Commun 334(1): 102-7.

Tirasophon, W., S. Yodmuang, W. Chinnirunvong, N. Plongthongkum and S. Panyim. 2007. Therapeutic inhibition of yellow head virus multiplication in infected shrimps by YHV-protease dsRNA. Antiviral Res 74(2): 150-5.

Tiu, S. H., J. Benzie and S. M. Chan. 2008. From hepatopancreas to ovary: molecular characterization of a shrimp vitellogenin receptor involved in the processing of vitellogenin. Biol Reprod 79(1): 66-74.

Tiu, S. H. and S. M. Chan. 2007. The use of recombinant protein and RNA interference approaches to study the reproductive functions of a gonad-stimulating hormone from the shrimp Metapenaeus ensis. FEBS J 274(17): 4385-95.

Tiu, S. H., J. G. He and S. M. Chan. 2007. The LvCHH-ITP gene of the shrimp (Litopenaeus vannamei) produces a widely expressed putative ion transport peptide (LVITP) for osmo-regulation. Gene 396(2): 226-35.

Treerattrakool, S., S. Panyim, S. M. Chan, B. Withyachumnarnkul and A. Udomkit. 2008. Molecular characterization of gonad-inhibiting hormone of Penaeus monodon and elucidation of its inhibitory role in vitellogenin expression by RNA interference. FEBS J 275(5): 970-80.

Wang, B., F. Li, B. Dong, X. Zhang, C. Zhang and J. Xiang. 2006. Discovery of the genes in response to white spot syndrome virus (WSSV) infection in Fenneropenaeus chinensis through cDNA microarray. Mar Biotechnol (NY) 8(5): 491-500.

Wang, B., F. Li, W. Luan, Y. Xie, C. Zhang, Z. Luo, L. Gui, H. Yan and J. Xiang. 2008a. Comparison of gene expression profiles of Fenneropenaeus chinensis challenged with WSSV and Vibrio. Mar Biotechnol (NY) 10(6): 664-75.

Wang, L., B. Zhi, W. Wu and X. Zhang. 2008b. Requirement for shrimp caspase in apoptosis against virus infection. Dev Comp Immunol 32(6): 706-15.

Westenberg, M., B. Heinhuis, D. Zuidema and J. M. Vlak. 2005. siRNA injection induces sequenceindependent protection in Penaeus monodon against white spot syndrome virus. Virus Res 114(12): 133-9.

Wong, Q. W., W. Y. Mak and K. H. Chu. 2008. Differential gene expression in hepatopancreas of the shrimp Metapenaeus ensis during ovarian maturation. Mar Biotechnol (NY) 10(1): 91-8.

$\mathrm{Wu}, \mathrm{W}$., R. Zong, J. Xu and X. Zhang. 2008. Antiviral phagocytosis is regulated by a novel Rabdependent complex in shrimp penaeus japonicus. J Proteome Res 7(1): 424-31. 
Wu, Y., L. Lu, L. S. Yang, S. P. Weng, S. M. Chan and J. G. He. 2007. Inhibition of white spot syndrome virus in Litopenaeus vannamei shrimp by sequence-specific siRNA. . Aquaculture 271: 21-30.

Xu, J., F. Han and X. Zhang. 2007. Silencing shrimp white spot syndrome virus (WSSV) genes by siRNA. Antiviral Res 73(2): 126-31.

Yodmuang, S., W. Tirasophon, Y. Roshorm, W. Chinnirunvong and S. Panyim. 2006. YHV-protease dsRNA inhibits YHV replication in Penaeus monodon and prevents mortality. Biochem Biophys Res Commun 341(2): 351-6.

Zhao, Z. Y., Z. X. Yin, S. P. Weng, H. J. Guan, S. D. Li, K. Xing, S. M. Chan and J. G. He. 2007. Profiling of differentially expressed genes in hepatopancreas of white spot syndrome virus-resistant shrimp (Litopenaeus vannamei) by suppression subtractive hybridisation. Fish Shellfish Immunol 22(5): 520-34. 